\title{
Inoculum Sources and Survival of Xanthomonas axonopodis pv. allii in Colorado
}

David H. Gent, National Forage Seed Production Research Center, United States Department of AgricultureAgricultural Research Service, Corvallis, OR 97331; Jillian M. Lang, Department of Bioagricultural Sciences and Pest Management, Colorado State University; Michael E. Bartolo, Department of Horticulture and Landscape Architecture, Colorado State University; and Howard F. Schwartz, Department of Bioagricultural Sciences, Colorado State University, Fort Collins 80523-1177

\begin{abstract}
Gent, D. H., Lang, J. M., Bartolo, M. E., and Schwartz, H. F. 2005. Inoculum sources and survival of Xanthomonas axonopodis pv. allii in Colorado. Plant Dis. 89:507-514.

Xanthomonas leaf blight, caused by the bacterium Xanthomonas axonopodis pv. allii, is an emerging disease of onion in the western United States and worldwide, but few management strategies have been developed because little is known about disease epidemiology and pathogen survival. Therefore, we sought to identify and quantify primary inoculum sources of the pathogen in Colorado. Growth chamber and field studies evaluated survival and dissemination of $X$. axonopodis pv. allii in association with weed, alternate host, and volunteer onion plants, irrigation water, and crop debris. Epiphytic $X$. axonopodis pv. allii was recovered from the foliage of nine asymptomatic weed species and Medicago sativa, but the bacterium was not recovered from plants in locations where an epidemic of Xanthomonas leaf blight did not occur the prior year. The bacterium also was isolated from volunteer onion with characteristic Xanthomonas leaf blight symptoms. A rifampicin mutant of X. axonopodis pv. allii strain $\mathrm{O} 177$ was recovered consistently from the irrigation tail water of onion fields inoculated with the bacterium; populations as large as $3.02 \times 10^{4} \mathrm{CFU} / \mathrm{ml}$ were recovered. $X$. axonopodis pv. allii was recovered from infested onion leaves 9 months after they were placed on the soil surface or buried to a depth of $25 \mathrm{~cm}$, but culturable populations of the pathogen decreased $10^{4}$ to $10^{6}$ more in buried leaves. Cultural practices that avoid or eliminate X. axonopodis pv. allii inoculum sources should reduce Xanthomonas leaf blight losses to onion.
\end{abstract}

Additional keywords: Allium cepa

Xanthomonas leaf blight of onion (Allium cepa), caused by Xanthomonas axonopodis pv. allii, is a yield-limiting disease in Colorado (22). Disease symptoms are varied but include leaves with lenticular water-soaked lesions that elongate into chlorotic streaks, necrosis, tip dieback, and stunting of plants that reduces bulb size. This reduction in leaf area results in undersized bulbs at harvest that can reduce yields significantly $(15,22,23)$. A bulb rot is not known to occur.

Corresponding author: H. F. Schwartz

E-mail: howard.schwartz@ colostate.edu

Financial support for these studies was provided by the Colorado Onion Association and USDA/ CSREES Crops at Risk Grant No. 2002-5110001905, entitled "Integrated Management of Xanthomonas Leaf Blight of Onion by Cultural Practices, Disease Forecasting, and Biologically-Based Pesticides." The use of trade, firm, or corporation names in this publication is for the information and convenience of the reader, and does not constitute an official endorsement or approval by the United States Department of Agriculture or the Agricultural Research Service of any product or service to the exclusion of others that may be suitable.

Accepted for publication 4 January 2005.

DOI: 10.1094/PD-89-0507

(C) 2005 The American Phytopathological Society
Few disease-management strategies have been developed for Xanthomonas leaf blight of onion because basic knowledge of $X$. axonopodis pv. allii survival and dissemination is lacking. The planting of pathogen-free seed may be essential because seed can be contaminated by $X$. axonopodis pv. allii (17), and this contamination appears important epidemiologically in tropical production regions (18). However, the role of seed contamination in semi-arid onion production regions is unknown. Crop rotation has been suggested in Barbados because $X$. axonopodis pv. allii strains common in this region reportedly attack leguminous hosts such as snap bean (Phaseolus vulgaris), lima bean (P. lunatus), and soybean (Glycine max) (13). Disease symptoms have not been observed in Colorado on any leguminous host, but $X$. axonopodis pv. allii colonized and persisted epiphytically on dry bean $(P$. vulgaris) and lentil (Lens culinaris) (D. H. Gent and H. F. Schwartz, unpublished data). The bacterium also can attack several Allium spp., such as A. fistulosum, A. sativum, A. porrum, and A. cepa var. ascalonicum $(4,7,9,16)$. Two Xanthomonas leaf blight-resistant cultivars have been identified (13), but are not adapted in Colorado and are no longer available commercially.
In the absence of effective cultural practices, host resistance, or biological controls, growers in Colorado rely upon copper-based bactericides to manage Xanthomonas leaf blight (22). Copper bactericides alone or amended with maneb suppress the disease, but spray applications must be applied preventatively and regularly (every 5 to 10 days) to be effective (21). Eight or more applications are made each season, but spray timing may be improved by disease forecasting (24). Copper resistance was not observed in a worldwide collection of $49 X$. axonopodis pv. allii strains (7), but was reported in strains from Barbados (14) and is common among other phytopathogenic bacteria $(3,11,25)$. Reliance upon copper bactericides alone for Xanthomonas leaf blight management increases onion production costs and is likely to select tolerant strains of $X$. axonopodis pv. allii. Alternative management strategies to reduce or replace copper bactericides are needed to improve grower profitability and delay or prevent the appearance of copper resistance.

Sustainable management of Xanthomonas leaf blight likely will require a multitactic approach that reduces or avoids primary inoculum sources, but these inoculum sources are unknown. Therefore, we sought to identify and quantify $X$. axonopodis pv. allii primary inoculum sources in Colorado onion-production regions.

\section{MATERIALS AND METHODS}

Bacterial strains and culture. A rifampicin mutant of $X$. axonopodis pv. allii strain $\mathrm{O} 177$ (American Type Culture Collection 508) was selected artificially as previously described (27), and is referred to as R-O177. Strain R-O177 is resistant to rifampicin at greater than $200 \mu \mathrm{g} / \mathrm{ml}$, but selection routinely was performed on nutrient agar amended with rifampicin at 50 or $100 \mu \mathrm{g} / \mathrm{ml}$ and cycloheximide at $50 \mu \mathrm{g} / \mathrm{ml}$. Other xanthomonads isolated from weeds, crops, or water were routinely cultured on nutrient agar at $29^{\circ} \mathrm{C}$. Bacterial strains were preserved in $15 \%$ nutrient glycerol broth at $-80^{\circ} \mathrm{C}$ for long-term storage.

Pathogenicity assays. All presumptive xanthomonads recovered were tested for pathogenicity on onion (cv. Vantage) and dry bean (cv. Sacramento light red kidney) in growth chamber assays. Dry bean inoculations were conducted to differentiate $X$. 
axonopodis pv. allii from pv. phaseoli because dry bean is commonly grown in rotation with onion in Colorado, and $X$. axonopodis pv. allii and pv. phaseoli both may survive epiphytically on some hosts $(1,5)$. The youngest, fully extended leaves of 8-week-old onion plants were pinpricked three times at $2.5-\mathrm{cm}$ intervals with a 22-gauge needle bearing a bacterial matrix of a given isolate removed from 72h-old nutrient agar culture plates. Each pin-pricked leaf area was inoculated with a droplet of bacterial matrix approximately equal in size to the needle tip. Plants serving as negative controls were pin-pricked with a sterile needle. Pathogenicity on dry bean was evaluated by spray inoculation as described below. A single colony of the isolate to be tested was picked from a 72h-old nutrient agar plate, added to $3 \mathrm{ml}$ of nutrient broth in 15-ml culture tubes, and incubated at $26^{\circ} \mathrm{C}$ with vigorous shaking ( 250 oscillations/min) for $24 \mathrm{~h}$. The bacterial cells were collected by centrifugation before adjusting to approximately $10^{7}$ $\mathrm{CFU} / \mathrm{ml}$ in sterile magnesium sulfatepotassium phosphate buffer $(0.01 \mathrm{M}$ magnesium sulfate and $0.01 \mathrm{M}$ potassium phosphate, $\mathrm{pH}$ 7.2). The 3- to 4-week-old dry bean plants were sprayed (Crown SpraTool; Aerovoe Industries, Inc., Gardnerville, NV) to runoff with the bacterial suspension. Control plants were inoculated with sterile buffer. The plants were placed in a growth chamber and incubated for 7 days with a temperature regime of $28^{\circ} \mathrm{C}$ day, $24^{\circ} \mathrm{C}$ night, light intensity of 350 $\mu \mathrm{Ms}^{-1} \mathrm{~m}^{-2}, 100 \%$ relative humidity, and daily misting with tap water to runoff. At least three plants were inoculated with each isolate. Plants were observed daily for symptom development. Isolates were considered nonpathogenic to a given host if disease symptoms failed to develop within 14 days.

Growth chamber epiphytic population assays. Epiphytic development of strain R-O177 was monitored on weeds commonly found in Colorado onion fields in growth chamber assays. Weed seed was collected from biotypes of each species found at and near the Colorado State University Agricultural Research, Development, and Education Center (ARDEC) near Fort Collins, CO from mature, symptomless weeds in fields where Xanthomonas leaf blight has not been observed. The plants from which seed was collected were not assayed for the presence of epiphytic $X$. axonopodis pv. allii, but we assumed epiphytic populations of the pathogen would be small or absent because they were collected from fields never planted to onion. Three seed of each of redroot pigweed (Amaranthus retroflexus), common lambsquarter (Chenopodium album), field bindweed (Convolvulus arvensis), yellow nutsedge (Cyperus esculentus), and hairy nightshade (Solanum sarrachoides) were planted individually into MetroMix 200 potting soil (Grace Sierra Horticultural Products Company, Milpitas, CA) in 1liter pots. Plants were grown under greenhouse conditions (temperature regime of approximately $24^{\circ} \mathrm{C}$ day, $20^{\circ} \mathrm{C}$ night and 14-h photoperiod, with approximately $2 \mathrm{~h}$ of supplemental incandescent lighting) until they were 3 to 4 (weeds) or 6 to 8 (onion) weeks old.

Twenty pots of each plant species were inoculated by spraying to runoff with a $10^{5}$ $\mathrm{CFU} / \mathrm{ml}$ bacterial suspension using a Crown Spratool. Inoculum of strain RO177 was cultured by inoculating $3 \mathrm{ml}$ of nutrient broth in 15-ml culture tubes, and incubating at $26^{\circ} \mathrm{C}$ with vigorous shaking ( 250 oscillations/min) for $24 \mathrm{~h}$. The bacterial cells were collected by centrifugation before adjusting to approximately $10^{5}$ $\mathrm{CFU} / \mathrm{ml}$ in sterile magnesium sulfatepotassium phosphate buffer. After inoculation, plants were allowed to air dry and then sampled immediately by removing all aboveground plant material from four pots of each species and placing each individually into a plastic bag. Another set of four pots of each plant species was destructively sampled each day for 4 days. An experimental unit consisted of one pot of a given plant species that contained three plants destructively sampled each day. Plants were maintained at a temperature regime of $28^{\circ} \mathrm{C}$ day, $24^{\circ} \mathrm{C}$ night, light intensity of $350 \mu \mathrm{Ms}^{-1} \mathrm{~m}^{-2}, 100 \%$ relative humidity, and were misted daily with tap water to runoff.

Harvested plant samples were weighed and placed into sterile 250-ml flasks containing $100 \mathrm{ml}$ of magnesium sulfatepotassium phosphate buffer, and shaken at 250 oscillations/min for $60 \mathrm{~min}$ at room temperature (approximately $22^{\circ} \mathrm{C}$ ). Aliquots $(100 \mu \mathrm{l})$ were diluted in 10 -fold serial dilutions in sterile magnesium sulfatepotassium phosphate buffer before plating in duplicate onto nutrient agar amended with rifampicin and cycloheximide at 50 $\mu \mathrm{g} / \mathrm{ml}$. Characteristic $X$. axonopodis pv. allii colonies were enumerated after $72 \mathrm{~h}$ of incubation at $26^{\circ} \mathrm{C}$, and a subset of rifampicin-resistant colonies were confirmed as $X$. axonopodis pv. allii by standard physiological and biochemical tests (19), including gram reaction, pigmentation on yeast dextrose carbonate medium, lack of fluorescence on King's medium B, indole test, growth on $0.1 \%$ tetrazolium chloride, oxidase test, starch hydrolysis, oxidative and fermentative utilization of glucose, production of catalase, production of $\mathrm{H}_{2} \mathrm{~S}$ from peptone, production of arginine dihydrolase, and casein hydrolysis test. The experiment was repeated once over time.

Recovery of $X$. axonopodis pv. allii from weed, crop, and volunteer onion plants. Weed, crop, and volunteer onion plant surveys were conducted in 2003 and 2004 in three major onion-growing regions of the state: the Arkansas Valley, northcentral Colorado, and northeastern Colo- rado. Commonly occurring weed, crop, and volunteer onion plants were collected within and adjacent to fields that were currently planted to or had been planted to onion the previous year. Five fields were surveyed for $X$. axonopodis pv. allii in 2003 and named for the county in which the field was located: Larimer, Morgan (two fields), Prowers, and Otero counties. In 2004, six fields were surveyed: Larimer, Morgan (two fields), Prowers, Otero, and Yuma counties. The Larimer and Otero fields surveyed in 2003 were surveyed in 2004, but fields at locations in 2003 and 2004 were distinct. Each site was surveyed at least once from May to July. Xanthomonas leaf blight was confirmed on the onion crops at sites 1 and 5 in 2002 and sites 1, 4 , and 5 in 2003. The disease was not observed in onion crops at the other sites during 2002 or 2003.

At each location, four bulked, 5- to $10-\mathrm{g}$ samples from each field were used for epiphyte recovery assays. Plant samples were weighed, placed into sterile $250-\mathrm{ml}$ flasks containing $100 \mathrm{ml}$ of magnesium sulfate-potassium phosphate buffer, and shaken at 250 oscillations/min for $60 \mathrm{~min}$ at room temperature (approximately $\left.22^{\circ} \mathrm{C}\right)$. Aliquots $(100 \mu \mathrm{l})$ were diluted in 10 -fold serial dilutions in sterile magnesium sulfate-potassium phosphate buffer before plating in duplicate onto modified MXP medium (6) containing kasugamycin at $50 \mathrm{mg} / \mathrm{liter}$, cephalexin at $30 \mathrm{mg} / \mathrm{liter}$, and cycloheximide at $50 \mathrm{mg} / \mathrm{liter}$, or plated in duplicate onto MXP medium using a spiral-plating system (Autoplate 4000; Spiral Biotech, Inc., Norwood, MA). Culture plates were incubated in the dark at $29^{\circ} \mathrm{C}$ for 72 to $96 \mathrm{~h}$ before observing plates for characteristic xanthomonad colonies surrounded by a zone of starch hydrolysis. Representative xanthomonad colonies were picked from plates and confirmed as $X$. axonopodis by physiological and biochemical tests and Biolog (Biolog, Inc., Hayward, CA) substrate utilization profiles. Identification to the pathovar level (X. axonopodis pv. allii or phaseoli) was determined by pathogenicity to onion or dry bean, respectively.

Recovery of $X$. axonopodis pv. allii from irrigation water. Furrow irrigation water entering and leaving onion fields was assayed for the presence of $X$. axonopodis pv. allii in 2003 and 2004. Field plots were established at ARDEC near Fort Collins, CO and the Arkansas Valley Research Center near Rocky Ford, CO. Plants were inoculated with $X$. axonopodis pv. allii strain R-O177 at $10^{6}$ to $10^{8} \mathrm{CFU} / \mathrm{ml}$ to initiate disease epidemics. Irrigation water entering and leaving these fields was collected and assayed for $X$. axonopodis pv. allii in 2003 (one field near Fort Collins, designated Larimer) and 2004 (two fields near Fort Collins designated Larimer 1 and 2, and one field near Rocky Ford, designated Otero). Cvs. Vantage and X-201 
were planted each year at Fort Collins and Rocky Ford, respectively.

Water used for irrigation in fields sampled near Fort Collins was derived from groundwater delivered to the field in buried plastic pipe, whereas water used for irrigation in the field sampled near Rocky Ford originated from the Arkansas River and was delivered to the field through the Rocky Ford Canal system. Each field was approximately $150 \mathrm{~m}$ in length, and was irrigated once to twice weekly, except when rainfall greater than $2.5 \mathrm{~cm}$ occurred since the previous irrigation. $X$. axonopodis pv. allii populations were measured from water collected during each irrigation in sterile $50-\mathrm{ml}$ centrifuge tubes from both the top and bottom ends of each field. Water sampling began when Xanthomonas leaf blight symptoms were first detected, and continued until the last irrigation before harvest. Water entering the fields was collected randomly from 3 to 10 locations as it left gated, polyvinvyl chloride delivery pipe (Fort Collins) or siphon tubes (Rocky Ford) before it contacted any plant or area of the field where plants were growing. Tail water was collected randomly in individual furrows before it mixed with water from other rows from 3 to 10 locations at the bottom of each field. Rows sampled randomly at the top of the field were not necessarily the same rows sampled randomly from the bottom of the field. An individual water sample collected on a given sampling date from a location was considered an experimental unit.

Water samples were placed at $4^{\circ} \mathrm{C}$ until assays were conducted. All samples were processed within $24 \mathrm{~h}$ after collection, but most samples were processed within $1 \mathrm{~h}$ after collection. Aliquots $(100 \mu \mathrm{l})$ were diluted in 10-fold serial dilutions in sterile magnesium sulfate-potassium phosphate buffer or spiral-plated directly (in duplicate) onto nutrient agar amended with rifampicin at $100 \mu \mathrm{g} / \mathrm{ml}$ and cycloheximide at $50 \mu \mathrm{g} / \mathrm{ml}$. Characteristic $X$. axonopodis pv. allii colonies were enumerated after 72 $\mathrm{h}$ of incubation at $29^{\circ} \mathrm{C}$, and a subset of rifampicin-resistant colonies were confirmed as $X$. axonopodis pv. allii by pathogenicity to onion and by physiological and biochemical tests.

Survival of $X$. axonopodis pv. allii in crop debris. $X$. axonopodis pv. allii survival in onion crop debris was determined in furrow-irrigated plots near Fort Collins and Rocky Ford from September 2003 to May (Rocky Ford) or June (Fort Collins) 2004. These sites were selected because they are in diverse onion-production regions separated by greater then $350 \mathrm{~km}$. Production practices, soil types, and irrigation water sources vary between Rocky Ford and Fort Collins (20). Leaves of onion cv. Vantage with characteristic Xanthomonas leaf blight symptoms were collected arbitrarily (irrespective of leaf age) in September 2003 from plants grown in experimental plots near Fort Collins. Leaves were collected only from plants that did not receive any bactericide treatment, and were dried at room temperature (approximately $24^{\circ} \mathrm{C}$ ) for $72 \mathrm{~h}$. Leaves were examined carefully, and any leaf with symptomology not typical of Xanthomonas leaf blight was discarded. The remaining diseased leaves were cut into $12.7-\mathrm{cm}$ lengths containing large lenticular-shaped, water-soaked lesions. Leaves with lesions covering at least $50 \%$ of the flat side of the leaf were collected and weighed. Four of these leaves were placed into a nylon stocking and placed into mesh onion sacks. Groups of four nylon stockings then were placed into mesh onion sacks to aid in recovery of the stockings. The mesh onion sacks were placed on the surface of a 75cm-wide soil bed and anchored with wooden stakes or buried $25 \mathrm{~cm}$ deep in order to simulate overwintering without or with deep tillage, respectively. The mesh sacks were placed in fields in September 2003. An experimental unit was considered an individual nylon stocking containing four diseased onion leaves, sampled on a given sampling date. The field near Fort Collins was left fallow and not irrigated until onion again was planted in April 2004. The field then was irrigated once to twice weekly until the study concluded. At Rocky Ford, the field was planted to winter wheat (Triticum aestivum) and was irrigated five times during the study.

One buried and one soil-surface mesh onion sack was recovered monthly from each field beginning 1 October 2003. A nylon stocking was removed from the mesh onion sack and placed into a sterile mortar before the addition of approximately $150 \mathrm{ml}$ of liquid nitrogen. The liquid nitrogen aided the maceration of the tissue but did not affect recovery of $X$. axonopodis pv. allii (data not presented). After evaporation of the nitrogen, the nylon stocking and associated diseased leaves were cut into small pieces with sterile scissors and ground with a sterile pestle. After the mortars thawed at room temperature, $20 \mathrm{ml}$ of sterile magnesium sulfatepotassium phosphate buffer was added and used to thoroughly rinse the nylon stocking and associated leaf material. Aliquots (100 $\mu \mathrm{l})$ were diluted in 10-fold serial dilutions in sterile magnesium sulfate-potassium phosphate buffer before plating in duplicate onto nutrient agar amended with rifampicin at $100 \mu \mathrm{g} / \mathrm{ml}$ and cycloheximide at $50 \mu \mathrm{g} / \mathrm{ml}$. Characteristic $X$. axonopodis pv. allii colonies were enumerated after 72 $\mathrm{h}$ of incubation at $29^{\circ} \mathrm{C}$, and a subset of rifampicin-resistant colonies were confirmed as $X$. axonopodis pv. allii by pathogenicity to onion and physiological and biochemical tests.

Statistical analyses. Growth chamber assays were organized as a completely randomized design with four replications. All bacterial population data were $\log$ transformed to achieve independently and normally distributed experimental errors with a common variance. Statistical analysis was performed using PROC MIXED in SAS (v. 9.1; SAS Institute, Cary, NC). Populations of $X$. axonopodis pv. allii recovered in water collected from the top and bottom of fields were analyzed by $t$ tests on each sampling date from each location. Populations of $X$. axonopodis pv. allii recovered in buried or nonburied crop debris were analyzed by one-sided $t$ tests assuming unequal variances on each sampling date from each location.

\section{RESULTS}

Growth chamber epiphytic population assays. $X$. axonopodis pv. allii population dynamics varied among weed species evaluated in growth chamber assays (Fig. 1). Culturable populations of the bacterium 4 days after inoculation increased 1.4, 1.7, and 1.8 logarithmic units/g of fresh weight on Convolvulus arvensis, Cyperus esculentus, and S. sarrachoides, respectively. During the same period, epiphytic populations decreased by 1.2 and 2.7 logarithmic units/g of fresh weight on A. retroflexus and Chenopodium album, respectively. Angular, water-soaked lesions and other symptoms characteristic of bacterial pathogen infection were not visible on any plants throughout the experiment.

Recovery of $X$. axonopodis pv. allii from weed, crop, and volunteer onion plants. $X$. axonopodis pv. allii and nonpathogenic xanthomonads were recovered from several weed and crop plants sampled in 2003 at sites where an epidemic of Xanthomonas leaf blight occurred the previous year (Table 1). At Larimer, epiphytic xanthomonads were recovered from volunteer onion, A. retroflexus, Cirsium arvense, Convolvulus arvensis, Echinochloa crusgalli, Malva neglecta, and Polygonum convolvulus. These isolates were yellowpigmented, nonfluorescent, gram-negative, obligate aerobes; positive for the presence of catalase; produced $\mathrm{H}_{2} \mathrm{~S}$ from cysteine; hydrolyzed casein and starch; were negative for the production of arginine dihydrolase, indole, and oxidase; and did not grow on $0.1 \%$ tetrazolium chloride medium. They were identified to the genus Xanthomonas based upon substrate utilization profiles on Biolog GN microplates (data not presented), but most were nonpathogenic to onion and dry bean. Isolates pathogenic to onion, and therefore classified as $X$. axonopodis pv. allii, were recovered only from $M$. neglecta.

At the Otero County site near Rocky Ford, an epidemic of Xanthomonas leaf blight occurred in 2002. In 2003, epiphytic $X$. axonopodis pv. allii was recovered from symptomless A. retroflexus, Anoda cristata, Kochia scoparia, M. sativa, and $S$. rostratum. Isolates recovered from these hosts were confirmed as $X$. axonopodis pv. 
from water entering field 2 on any sampling date.

At Rocky Ford in 2004, only two irrigation events were sampled after Xanthomonas leaf blight symptoms were apparent in the field because timely and consistent rainfall supplied much of the water requirement for the crop. On 1 and $14 \mathrm{Au}-$ gust, no xanthomonads were recovered from irrigation water entering the field, but $1.55 \times 10^{1}$ and $8.71 \times 10^{2} \mathrm{CFU} / \mathrm{ml}$ were recovered from irrigation water at the bottom of the field, respectively.

Survival of $X$. axonopodis pv. allii in crop debris. Culturable populations of $X$. axonopodis pv. allii were greater in onion leaves on the soil surface than in buried leaves at Fort Collins or Rocky Ford on all sampling dates except the first (Table 3). At Fort Collins, culturable $X$. axonopodis pv. allii populations decreased more than 100 -fold in leaves on the soil surface over the 9-month duration of the study. In the same time period, culturable $X$. axonopodis pv. allii populations decreased more than $10^{9}$-fold in leaves buried $25 \mathrm{~cm}$ deep. Similarly, at Rocky Ford, populations in leaves left on the surface decreased greater than $10^{3}$-fold over the 8 months they were monitored, and decreased greater than $10^{7}$ fold in buried leaves. On the last sampling date, $8.3 \times 10^{7}$ and $1.3 \times 10^{6} \mathrm{CFU} /$ leaf were cultured from leaves left on the soil surface at Fort Collins and Rocky Ford, respectively. Culturable populations in buried leaves on the same dates were 9.1 and $5.3 \times 10^{2} \mathrm{CFU} / \mathrm{leaf}$ from Fort Collins and Rocky Ford, respectively.

\section{DISCUSSION}

Xanthomonas leaf blight first was observed in Colorado in 1996, and annual occurrences of the disease since its appearance suggest that it has become endemic in southern Colorado. Management of Xanthomonas leaf blight largely has been limited to copper bactericide applications because basic elements of its epidemiology are unknown and inoculum sources have not been identified. In this study, we have identified and quantified several primary inoculum sources of $X$. axonopodis pv. allii. Reservoirs of the pathogen were identified in or on other crop and weed species, volunteer onion plants, contaminated irrigation water, and infested onion crop debris. The relative importance of these inoculum sources to the epidemiology and management of Xanthomonas leaf blight development is unknown, but the design of onion production and pest management systems may need to eliminate multiple $X$. axonopodis pv. allii inoculum sources to reduce recurring losses from Xanthomonas leaf blight.

Several weeds common in onionproduction systems in Colorado were found to be sources of epiphytic $X$. axonopodis pv. allii, as well as $X$. axonopodis pv. phaseoli and other xanthomonads. X. axonopodis pv. allii was recovered only from sites where Xanthomonas leaf blight occurred the previous year, and its recovery from many weeds was not consistent across sites or time. In 2003, X. axonopodis pv. allii was recovered only from $M$. neglecta at the Larimer County site, but was recovered from five weed species and alfalfa from the Otero County site; an epidemic of Xanthomonas leaf blight occurred at both locations in 2002. Similarly, in 2004 , the bacterium was not recovered from any weed or other crop plants at the Larimer, Morgan, or Prowers Counties sites but was recovered from six weed species at the Yuma County site. In growth chamber studies under conditions favorable to the pathogen, epiphytic populations

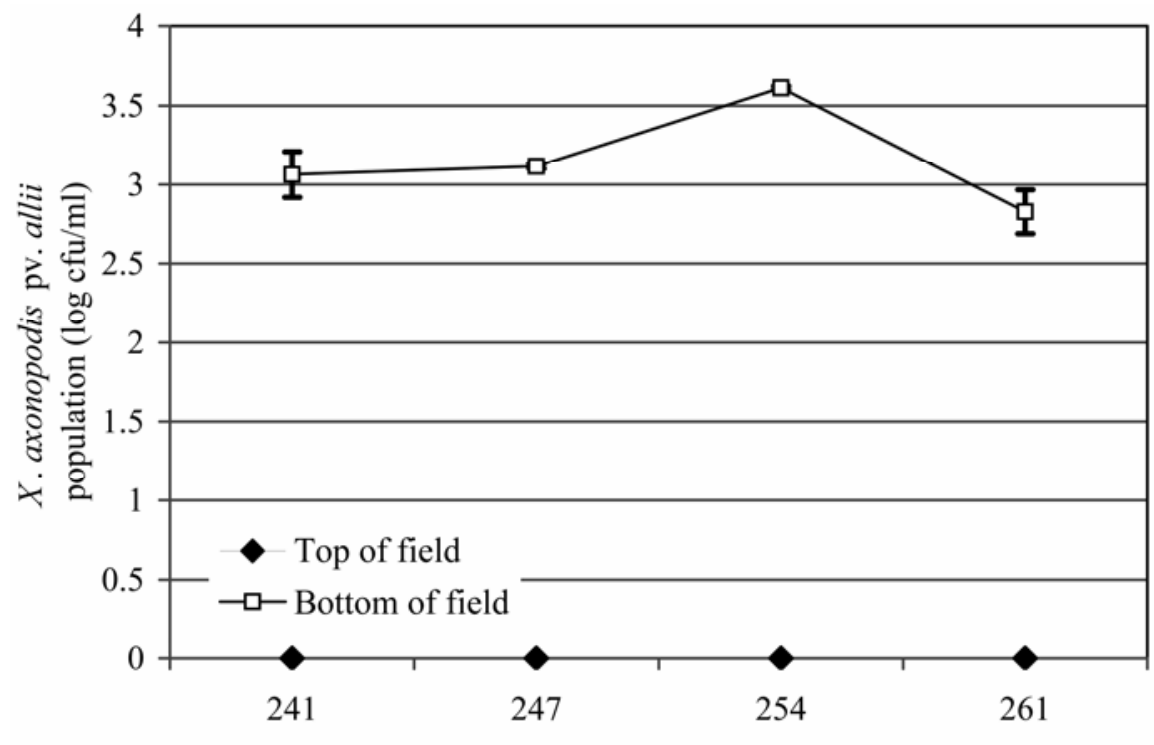

Day of year

Fig. 2. Recovery of Xanthomonas axonopodis pv. allii strain R-O177 in surface irrigation water entering and leaving an onion field near Fort Collins, $\mathrm{CO}$ in 2003 during an epidemic of Xanthomonas leaf blight. X. axonopodis pv. allii populations in water were measured from water collected during each irrigation. Water sampling began when Xanthomonas leaf blight symptoms were first detected, and continued until the last irrigation before harvest. Culturable $X$. axonopodis pv. allii populations were estimated by plating serial dilutions of irrigation water on nutrient agar amended with rifampicin and cycloheximide.

Table 2. Location and isolation of Xanthomonas spp. from various plant species at sites in Colorado during $2004^{\mathrm{a}}$

\begin{tabular}{|c|c|c|c|c|c|}
\hline Larimer $^{\mathbf{b}}$ & Morgan (1) & Morgan (2) ${ }^{c}$ & Otero $^{d}$ & Prowers $^{\mathrm{e}}$ & Yuma $^{\mathbf{f}}$ \\
\hline Allium cepa** & Allium сера & Amaranthus retroflexus ${ }^{* *}$ & Allium cepa** & Cyperus esculentus** & Allium cepa $* *$ \\
\hline Amaranthus retroflexus** & Kochia scoparia & Kochia scoparia & Convolvulus arvensis** & Helianthus annuus $* *$ & Amaranthus retroflexus** \\
\hline Helianthus annuus** & Solanum sarrachoides & Sorghum halepense ${ }^{* *}$ & Glycine $\max$ & Kochia scoparia** & Cenchrus longispinus** \\
\hline Kochia scoparia & $\ldots$ & $\ldots$ & Kochia scoparia & Medicago sativa** & Chenopodium album** \\
\hline Lens culinaris** & $\ldots$ & $\ldots$ & $\ldots$ & Solanum rostratum $* *$ & Helianthus annuus** \\
\hline Polygonum convolvulus & $\ldots$ & $\ldots$ & $\ldots$ & Taraxacum officinale** & Kochia scoparia** \\
\hline Solanum sarrachoides & $\ldots$ & $\ldots$ & $\ldots$ & $\ldots$ & Solanum sarrachoides** \\
\hline
\end{tabular}

a At each location, four bulked, 5- to 10-g samples from each field were used in leaf rinse assays to recover epiphytic xanthomonads; $* *=$ tested positive for Xanthomonas sp. Presumptive xanthomonads were confirmed as X. axonopodis by physiological and biochemical tests and Biolog (Biolog, Inc., Hayward, CA) substrate utilization profiles. Identification to the pathovar level (X. axonopodis pv. allii or phaseoli) was determined by pathogenicity to onion or dry bean. Nonpathogenic xanthomonads were recovered from several weed hosts, including A. retroflexus, Cirsium arvense, Convolvulus arvensis, Cyperus esculentus, $H$. annuus, $K$. scoparia, L. culinaris, $M$. sativa, S. rostratum, and T. officinale.

b Planted to onion from 2002 to 2004 at Larimer. Larimer was sampled on 27 May and 9 June. Xanthomonas leaf blight was confirmed in 2002 and 2003.

c Planted to dry bean in 2003 and onion in 2004. Morgan (1) was sampled on 7 June and Morgan (2) was sampled on 13 July.

d Planted to onion in 2002 and 2003 and soybean in 2004. Otero was sampled on 8 June. Xanthomonas leaf blight was confirmed in 2002 and 2003.

e Planted to alfalfa in 2002 and 2003 and onion in 2004. Sampling was conducted on 7 June.

f Planted to onion in 2002 and 2003 and corn in 2004. Sampling was conducted on 7 June. Xanthomonas leaf blight was confirmed in 2003. 


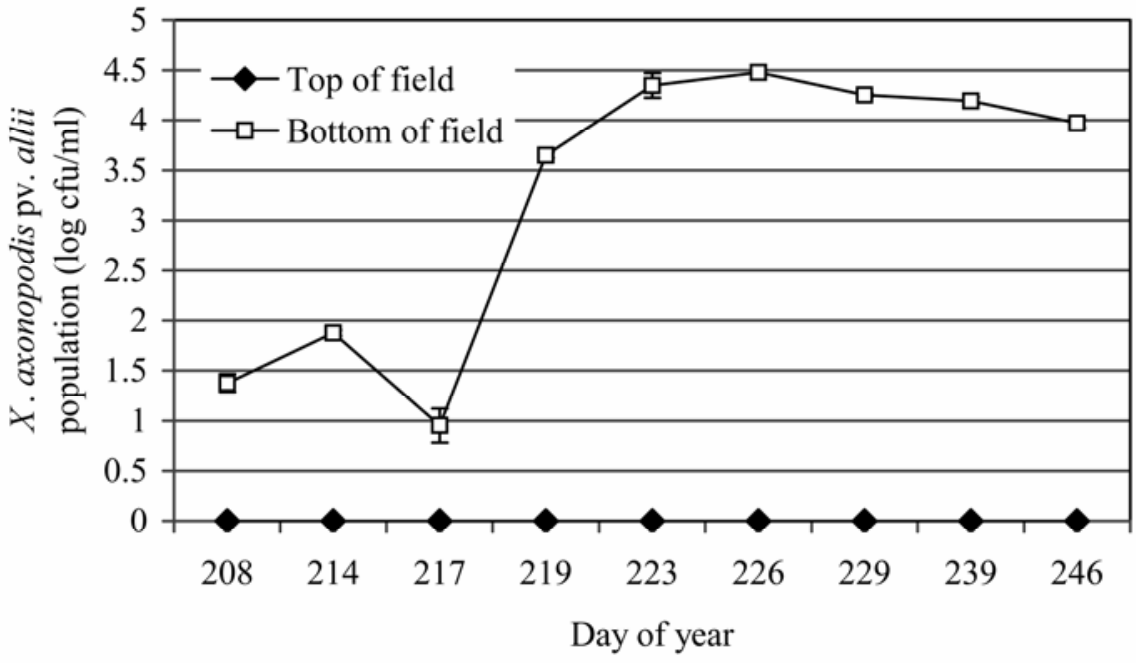

Fig. 3. Recovery of Xanthomonas axonopodis pv. allii strain R-O177 in surface irrigation water entering and leaving onion field no. 1 near Fort Collins, CO in 2004 during an epidemic of Xanthomonas leaf blight. X. axonopodis pv. allii populations in water were measured from water collected during each irrigation. Water sampling began when Xanthomonas leaf blight symptoms were first detected, and continued until the last irrigation before harvest. Culturable $X$. axonopodis pv. allii populations were estimated by plating serial dilutions of irrigation water on nutrient agar amended with rifampicin and cycloheximide.

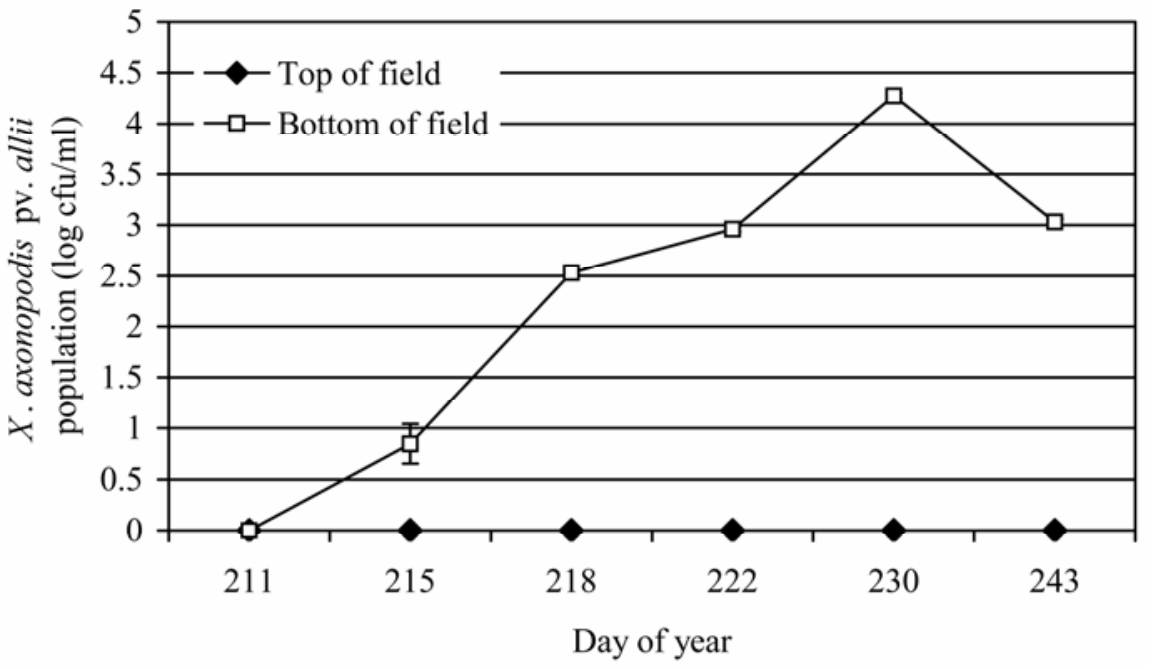

Fig. 4. Recovery of Xanthomonas axonopodis pv. allii strain R-O177 in surface irrigation water entering and leaving onion field no. 2 near Fort Collins, CO in 2004 during an epidemic of Xanthomonas leaf blight. X. axonopodis pv. allii populations in water were measured from water collected during each irrigation. Water sampling began when Xanthomonas leaf blight symptoms were first detected, and continued until the last irrigation before harvest. Culturable $X$. axonopodis pv. allii populations were estimated by plating serial dilutions of irrigation water on nutrient agar amended with rifampicin and cycloheximide.

of $X$. axonopodis pv. allii increased on three of five weed species evaluated, but decreased nearly 1,000-fold on Chenopodium album. Plant species and environmental conditions are known to influence epiphytic bacterial populations (12), but the conditions that allow $X$. axonopodis pv. allii to successfully colonize weeds are unclear. When the results of growth chamber and field studies are taken together, they suggest that not all weed species support epiphytic growth of $X$. axonopodis pv. allii. We recovered $X$. axonopodis pv. phaseoli and nonpathogenic xanthomonads from several weed and crop plants, and symptoms were present, but that few weeds outside of such fields harbored epiphytic $X$. axonopodis pv. phaseoli, and these epiphytic populations were short lived. Within 7 days after harvest, epiphytic X. axonopodis pv. phaseoli cells were not detected on weeds within the field. Similarly, Barak et al. (2) reported that $X$. campestris pv. vitians was not recovered unless lettuce (Lactuca sativa) with bacterial leaf spot symptoms was nearby, and the bacterium did not survive on weeds during a 2-month fallow period between lettuce crops. In the current study, $X$. axonopodis pv. allii was recovered from only a few weeds in or near fields where Xanthomonas leaf blight was present less than 10 months earlier. In Colorado, onion crops generally are grown in 2- or 3-year rotations with small grains, dry bean, corn, and other vegetable crops (21). Because $X$. axonopodis pv. allii does not appear to persist epiphytically for longer than one season on weeds species, weeds are not likely to be the primary means for bacterial persistence in the absence of onion.

Volunteer onion, however, consistently was a source of $X$. axonopodis pv. allii. Xanthomonas leaf blight symptoms or epiphytic $X$. axonopodis pv. allii were observed on or recovered from volunteer onion at four or five sites where Xanthomonas leaf blight occurred the previous year. At site 5 in 2003 and site 5 in 2004, Xanthomonas leaf blight symptoms were observed on volunteer onion before the disease appeared in nearby onion fields, suggesting that volunteer onion is an earlyseason source of the pathogen.

Irrigation water appears to be an efficient medium for the dispersal of $X$. axonopodis pv. allii. Large populations of the bacterium, sometimes in excess of $10^{4}$ $\mathrm{CFU} / \mathrm{ml}$, were recovered from irrigation water leaving fields where Xanthomonas leaf blight symptoms were observed. However, irrigation water originating from groundwater was not found to harbor $X$. axonopodis pv. allii when plated onto rifampicin-amended nutrient agar or modified MXP medium (data not presented). Onion crops are irrigated primarily by furrow irrigation in Colorado (21), and the tail water leaving these fields is returned to canal systems and reused in other, downstream fields. Reuse of contaminated water could easily introduce inoculum onto onion foliage by splashing or direct contact because leaves often extend into furrows. Xanthomonads are known to be readily disseminated by irrigation water $(10,26)$; therefore avoiding reuse of irrigation water and relying upon groundwater for irrigation where possible should reduce this source of $X$. axonopodis pv. allii.

Crop debris can be an epidemiologically important source of xanthomonads $(2,8,20)$, and we found significant populations of $X$. axonopodis pv. allii overwintering in diseased onion leaves buried $25 \mathrm{~cm}$ 
Table 3. Survival of Xanthomonas axonopodis pv. allii strain R-O177 in leaves of onion cv. Vantage buried $25 \mathrm{~cm}$ deep or left on the soil surface near Fort Collins, $\mathrm{CO}$

\begin{tabular}{|c|c|c|c|c|c|c|c|c|c|}
\hline \multirow[b]{2}{*}{ Variable } & \multicolumn{9}{|c|}{ Logarithmic CFU/leaf, sampling date ${ }^{a}$} \\
\hline & Oct 2003 & Nov 2003 & Dec 2003 & Jan 2004 & Feb 2004 & Mar 2004 & Apr 2004 & May 2004 & Jun 2004 \\
\hline \multicolumn{10}{|c|}{ Fort Collins } \\
\hline Buried & 10.03 & 9.60 & 10.84 & 9.08 & 8.46 & 9.85 & 8.97 & 7.99 & 7.92 \\
\hline Surface & 10.12 & 6.89 & 4.95 & 5.33 & 3.95 & 4.06 & 3.77 & 3.21 & 0.96 \\
\hline$t$ Test $^{\mathrm{b}}$ & 0.5000 & 0.0018 & 0.0007 & 0.0004 & 0.0002 & $<0.0001$ & $<0.0001$ & $<0.0001$ & 0.0005 \\
\hline \multicolumn{10}{|c|}{ Rocky Ford } \\
\hline Surface & 10.94 & 9.03 & 8.82 & 9.01 & 8.14 & 8.13 & 8.88 & 6.12 & $\ldots$ \\
\hline Buried & 11.02 & 7.13 & 4.92 & 3.81 & 5.10 & 6.52 & 2.46 & 2.73 & $\ldots$ \\
\hline$t$ Test $^{\mathrm{b}}$ & 0.5213 & 0.0008 & $<0.0001$ & $<0.0001$ & 0.0006 & 0.0372 & 0.0001 & 0.0052 & $\ldots$ \\
\hline
\end{tabular}

${ }^{a}$ Leaves of onion cv. Vantage with characteristic Xanthomonas leaf blight symptoms were arbitrarily collected in September 2003 from experimental plots near Fort Collins from plants that did not receive any bactericide treatment. Four of these leaves were placed into a nylon stocking and placed into mesh onion sacks. Groups of four nylon stockings then were placed into mesh onion sacks to aid in recovery of the stockings. The mesh onion sacks were placed on the soil surface or buried $25 \mathrm{~cm}$ deep in order to simulate overwintering without or with deep tillage, respectively. An experimental unit was considered an individual nylon stocking containing four diseased onion leaves, sampled on a given sampling date. Samples were collected monthly beginning 1 October 2003, ground with a pestle and mortar, and X. axonopodis pv. allii was recovered onto rifampicin-amended nutrient agar.

${ }^{\mathrm{b}}$ Probability observed differences in culturable $X$. axonopodis pv. allii CFU among samples on a given date is due to chance. One-sided student $t$ tests assumed unequal variances.

deep or left on the soil surface. Culturable populations of the bacterium were decreased eight to nine orders of magnitude in buried leaves over the 9-month time course of this study, but decreased only two to four orders of magnitude in leaves left on the soil surface. Greater than $10^{6}$ $\mathrm{CFU} /$ leaf were recovered from onion leaves on the soil surface after 8 months, but only $10^{4} \mathrm{CFU} /$ leaf were recovered from buried leaves when sampled in March, the month in which most onions are planted in Colorado. Deep incorporation of diseased crop debris would not eliminate overwintering populations of the bacterium before an onion crop is planted the following spring. In June, small populations (less than $10 \mathrm{CFU} / \mathrm{leaf}$ ) of the pathogen were recovered from buried leaves, and these bacteria likely would not survive until the following season. Therefore, prompt and thorough incorporation of infested crop debris after harvest and rotation of at least 2 years between onion crops are necessary to reduce and avoid overwintering populations of $X$. axonopodis pv. allii in Colorado. However, the persistence of buried or unincorporated onion crop debris is unknown in Colorado, and longer crop rotations may be necessary under certain conditions or production practices.

Integrated management of Xanthomonas leaf blight in Colorado may need to consider multiple inoculum sources of $X$. axonopodis pv. allii, including contaminated seed $(17,18)$, weeds, leguminous crops, infested crop debris, irrigation water, and volunteer onion. The contribution of these potential inoculum sources on Xanthomonas leaf blight appearance or severity remain speculative, and require more investigation to elucidate their relative importance to disease epidemiology in Colorado and elsewhere. Nonetheless, onion production systems that practice strict sanitation of weed and volunteer onion plants, follow a 2-year or longer rotation to nonhosts such as small grains, avoid reuse of irrigation tail water, and promote rapid breakdown of crop debris by deep tillage should reduce $X$. axonopodis pv. allii survival and minimize reliance upon copper bactericides for disease management.

\section{ACKNOWLEDGMENTS}

We thank E. Frank and K. Otto for excellent technical support.

\section{LITERATURE CITED}

1. Angeles-Ramos, R., Vidaver, A. K., and Flynn, P. 1991. Characterization of epiphytic Xanthomonas campestris pv. phaseoli and pectolytic xanthomonads recovered from symptomless weeds in the Dominican Republic. Phytopathology 81:677-681.

2. Barak, J. D., Koike, S. T., and Gilbertson, R. L. 2001. Role of crop debris and weeds in the epidemiology of bacterial leaf spot of lettuce in California. Plant Dis. 85:169-178.

3. Bender, C. L., and Cooksey, D. A. 1986. Indigenous plasmids in Pseudomonas syringae pv. tomato: Conjugative transfer and role in copper resistance. J. Bacteriol. 165:534-541.

4. Bowen, P., Gibbs, H. A., and O'Garro, L. W. 1996. Garlic, chives, shallot, and leek are alternative hosts to Xanthomonas campestris, the pathogen of leaf blight of onion. Proc. Int. Congr. Plant Pathol. 7:696.

5. Cafati, C. R., and Saettler, A. W. 1980. Role of nonhost species as alternate inoculum sources of Xanthomonas phaseoli. Plant Dis. 64:194196.

6. Claflin, L. E., Vidaver, A. K., and Sasser, M. 1987. MXP, a semi-selective medium for Xanthomonas campestris pv. phaseoli. Phytopathology 77:730-734.

7. Gent, D. H., Schwartz, H. F., Ishimaru, C. A., Louws, F. J., Cramer, R. A., and Lawrence, C. B. 2002. Polyphasic characterization of Xanthomonas strains from onion. Phytopathology 94:184-195.

8. Gilbertson, R. L., Rand, R. E., and Hagedorn, D. J. 1990. Survival of Xanthomonas campestris pv. phaseoli and pectolytic strains of $X$. campestris in bean debris. Plant Dis. 74:322327.

9. Kadota, I., Uehara, K., Shinohara, H., and Nishiyama, K. 2000. Bacterial blight of Welsh onion: A new disease caused by Xanthomonas campestris pv. allii pv. nov. J. Gen. Plant Pathol. 66:310-315.

10. King, C. J., and Brinkerhoff, L. A. 1949. The dissemination of Xanthomonas malvacearum by irrigation water. Phytopathology 39:88-90.
11. Minsavage, G. V., Canteros, B. I., and Stall, R E. 1990. Plasmid-mediated resistance to streptomycin in Xanthomonas campestris pv. vesicatoria. Phytopathology 80:719-723.

12. O'Brien, R. D., and Lindow, S. E. 1989. Effect of plant species and environmental conditions on epiphytic population sizes of Pseudomonas syringae and other bacteria. Phytopathology 79:619-627.

13. O'Garro, L. W., and Paulraj, L. P. 1997. Onion leaf blight caused by Xanthomonas campestris: Alternative hosts and resistant onion genotypes. Plant Dis. 81:978-982.

14. Paulraj, L., and O'Garro, L. W. 1992. Aspects of the epidemiology of a leaf blight of onion in Barbados. Pages 89-96 in: Proc. Tenth Annual Conf. Barbados Soc. Technol. Agric. St. Michael, Barbados.

15. Paulraj, L., and O'Garro, L. W. 1993. Leaf blight of onion in Barbados caused by Xanthomonas campestris. Plant Dis. 77:198201.

16. Roumagnac, P., Gagnevin, L., Gardan, L., Sutra, L., Manceau, C., Dickstein, E. R., Jones, J. B., Rott, P., and Pruvost, O. 2004. Polyphasic characterization of xanthomonads isolated from onion, garlic and Welsh onion (Allium spp.) and their relatedness to different Xanthomonas species. Int. J. Syst. Evol. Microbiol. 54:15-24

17. Roumagnac, P., Gagnevin, L., and Pruvost, O. 2000. Detection of Xanthomonas sp., the causal agent of onion bacterial blight, in onion seeds using a newly developed semi-selective isolation medium. Eur. J. Plant Pathol 106:867-877.

18. Roumagnac, P., Pruvost, O., Chiroleu, F., and Hughes, G. 2004. Spatial and temporal analyses of bacterial blight of onion caused by Xanthomonas axonopodis pv. allii. Phytopathology 94:138-146.

19. Schaad, N. W., Jones, J. B., and Chun, W., eds. 2001. Laboratory Guide for the Identification of Plant Pathogenic Bacteria, 3rd ed. The American Phytopathological Society Press, St. Paul, MN.

20. Schaad, N. W., and White, W. C. 1974. Survival of Xanthomonas campestris in soil. Phytopathology 64:1518-1520.

21. Schwartz, H. F., and Bartolo, M. E. 1995. Colorado Onion Production and Integrated Pest Management. Bull. 547A. Colorado State University, Ft. Collins.

22. Schwartz, H. F., and Otto, K. J. 1998. Onion bacterial disease management in Colorado. Pages 214-218 in: Proc. 1998 Natl. Onion (and other Allium) Res. Conf. Sacramento, CA.

23. Schwartz, H. F., and Otto, K. 2000. First report 
of a leaf blight of onion by Xanthomonas campestris in Colorado. Plant Dis. 84:922.

24. Schwartz, H. F., Otto, K. L., and Gent, D. H. 2003. Relation of temperature and rainfall to development of Xanthomonas and Pantoea leaf blights of onion in Colorado. Plant Dis. 87:11-14.
25. Stall, R. E., Loschke, D. C., and Jones, J. B. 1986. Linkage of copper resistance and avirulence loci on a self-transmissible plasmid in Xanthomonas campestris pv. vesicatoria. Phytopathology 76:240-243.

26. Steadman, J. R., Maier, C. R., Schwartz, H. F., and Kerr, E. D. 1975. Pollution of surface irri- gation waters by plant pathogenic organisms. Water Resour. Bull. 11:796-804.

27. Weller, D. M., and Saettler, A. W. 1978. Rifampin-resistant Xanthomonas phaseoli var. fuscans and Xanthomonas phaseoli: Tools for field study of bean blight bacteria. Phytopathology 68:778-781. 